\title{
Requirements and Planning of Badliya Village for converting it into Smart Village Category in Banswara, Rajasthan
}

\author{
Sangeeta Choudhary, Om Prakash Prajapat, Bhuvnesh Suthar, Suresh Kumar, Mahendra \\ Kumar
}

\begin{abstract}
India is developing country and around 67\% population is lived in villages. Large mass of people are migrating from rural area to urban area due to scarcity of basic facilities in villages like schools, roads, hospitals, electricity, pure water, proper sewage system and hygienic conditions for better life. So it is need of the hour to identify the requirements of villages to converting it into smart village category for stopping the migration of rural population to urban area, as it will control the load of excessive population on urban cities. In this project Badliya village in Udaipur was selected for survey to make out the necessities and planning of different facilities according to requirements of village. This type of projects will be helpful for developing Smart Villages in India.
\end{abstract}

Keywords: Smart Village, Infrastructure, Field Survey, Road Network.

\section{INTRODUCTION}

In India, most of the population lives in the rural area. In our country there are $6,00,000$ villages out of them $1,25,000$ villages are backward so there is a need for designing and building the village as a smart village[1]. This project ensures that the people are made social and modern without disturbing their lifestyle but by providing them more things or we can say opportunities to order to explore their selves. The concept of this project is taken from "Swaraj" and "suraj village" introduced by Mahatma Gandhi.

\section{Purpose of the Project}

This project is introduced in order to make the villages smart. According to this project, smart word means a prosperous village, aware about the policies and schemes, giving equal opportunity to everyone for development and familiar with all the basic requirements provided along with digitalization and urbanization.

Revised Manuscript Received on March 15, 2020.

Sangeeta Choudhary, Department of Civil Engineering, Techno India NJR Institute of Technology, Udaipur, Rajasthan, India.

E-mail:Sangeeta27apr@gmail.com

Om Prakash Prajapat, Department of Civil Engineering, Techno India NJR Institute of Technology, Udaipur, Rajasthan, India.

Bhuvnesh Suthar, Department of Civil Engineering, Techno India NJR Institute of Technology, Udaipur, Rajasthan, India.

Suresh Kumar, Department of Civil Engineering, Techno India NJR Institute of Technology, Udaipur, Rajasthan, India.

Mahendra Kumar, Department of Civil Engineering, Techno India NJR Institute of Technology, Udaipur, Rajasthan, India.
The basic idea of smart village is to assemble society efforts and strong point of people from various streams and put together it with information technology to provide benefits to the rural community [2], [3].

\section{Criteria for "Smart Village" for Infrastructure Solution} [4], [5]:

- Fully developed roads

- Network and $100 \%$ WI-FI village

- 24 hours electricity supply

- Proper drainage system

- Highly developed government buildings

- Solar panels on every government building.

\section{METHODOLOGY}

The study area Badliya is considered in the gram panchayat tehsil Ganoda and it is in Banswara district. The longitude and latitude of Badliya are $23^{\circ} 36^{\prime} 58.9^{\prime \prime} \mathrm{N}$ and $74^{\circ} 21^{\prime} 24.7^{\prime \prime} \mathrm{E}$ respectively. Banswara is nearest city to Badliya which is approximately $13 \mathrm{~km}$ away.

Following methods were adopted for identify the problems in way to make out this village into Smart village:

1. GIS Survey through Google earth for location of study area and road network around and inside the village.

2. Field survey through interviews of villagers and government authorities.

3. Planning required infrastructure for Smart village on the basis information through GIS and Field Survey

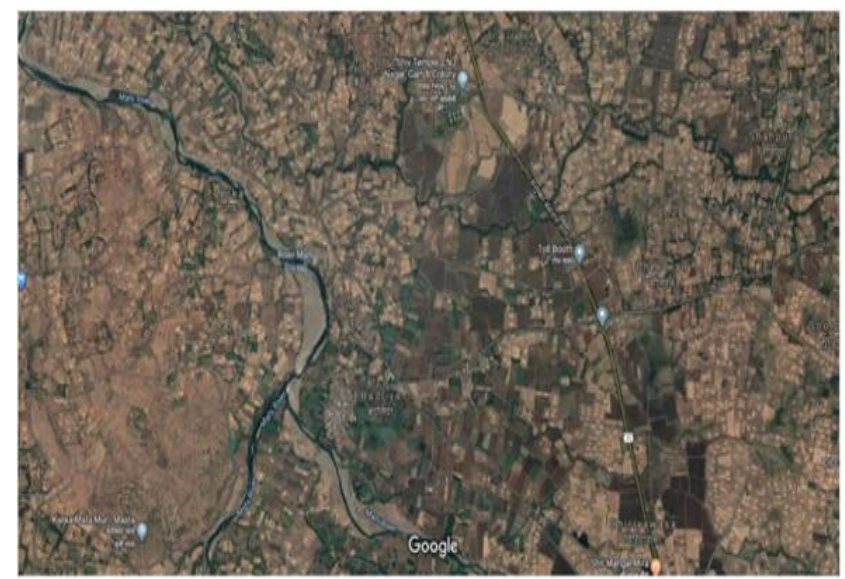

Fig. 1: Location of Badliya Village 


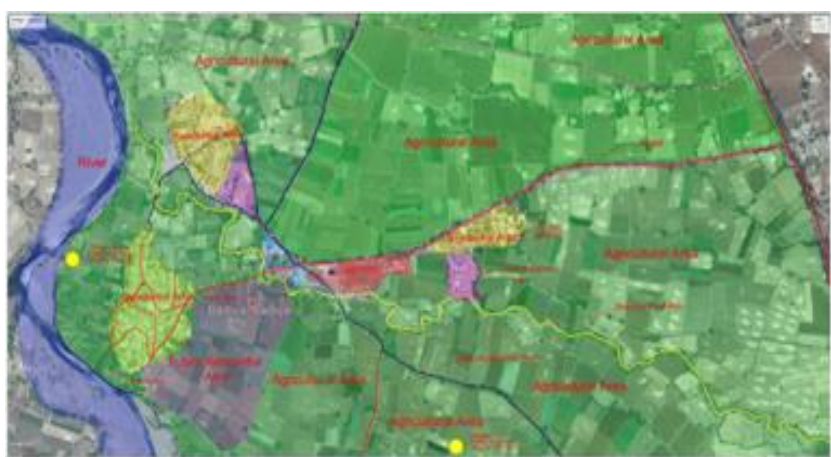

Fig. 2: Road Network around the Village

Table I: Data on the basis of Field Survey and Online data

\begin{tabular}{|c|c|}
\hline PARAMETERS & SURVEYED DATA \\
\hline $\begin{array}{l}\text { Water supply system } \\
\text { - River } \\
\text { - Borewell } \\
\text { - Well }\end{array}$ & 1 \\
\hline Community hall & 1 \\
\hline Bank & - \\
\hline Source of income of villagers & $\begin{array}{l}\text { - } \text { Farming } \\
\text { - Daily wage labour } \\
\text { - } \text { Business } \\
\text { - } \text { Abroad } \\
\end{array}$ \\
\hline $\begin{array}{l}\text { Educational facility: } \\
\text { - Senior Secondary School } \\
\text { - Primary school } \\
\text { - Rajiv Gandhi Seva } \\
\text { Kendra }\end{array}$ & $\begin{array}{l}1 \\
3 \\
1\end{array}$ \\
\hline Health facility & 1 \\
\hline Main crops & $\begin{array}{ll}\text { - Rabi- Makka } \\
\text { - Kharif- Wheat }\end{array}$ \\
\hline Sex ratio & 981 \\
\hline Child sex ratio & 1014 \\
\hline Total No. of Houses & 464 \\
\hline Population & 1985 \\
\hline Literacy & $64.94 \%$ \\
\hline
\end{tabular}

\section{RESULT AND DISCUSSION}

Major problems in lakhwali village for infrastructure solution:

- Undeveloped Roads: The major problems in the village are undeveloped roads and this condition gets worsened in

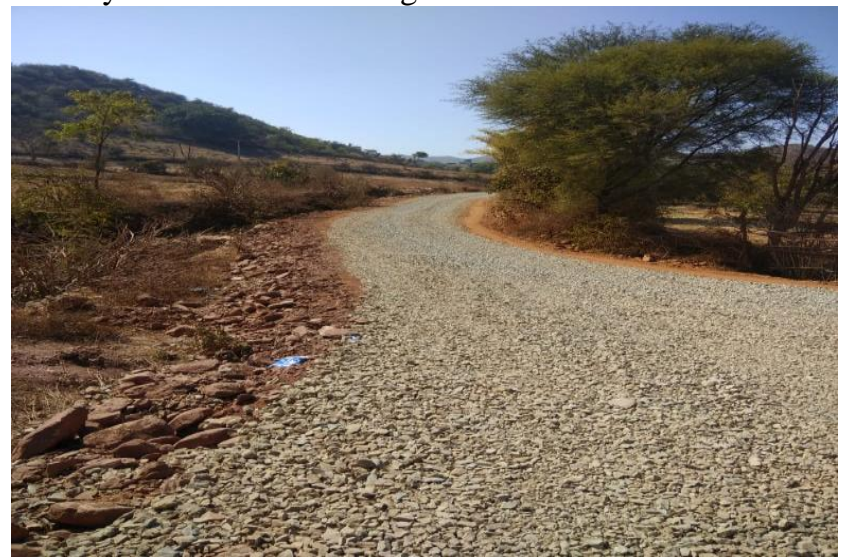

Fig. 3: Undeveloped Road System in Village rainy season as seen in Fig. 3 .

- No availability of mobile network.

- Less water is available for irrigation purpose: Except rainy season, there is no source of water for irrigation purpose in the village. Those who have their own water sources can irrigate their farms in other seasons otherwise they are left uncultivated.

- Improper drainage system: The sewage pipes from their houses are left open to the roads and all the liquid waste from their houses damage the roads and the inner roads are not even so well developed. This kind of improper sanitation ruins the cleanliness of the village in Fig. 4

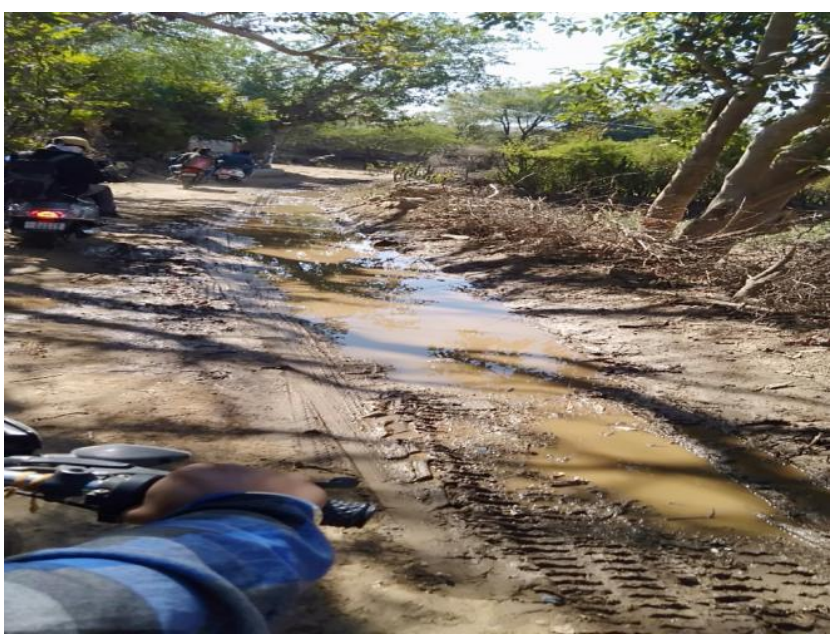

Fig. 4: Improper Drainage Condition

- Scarcity of potable water: Potable water isn't easily accessible to them. The water reservoir, there isn't having much capacity and it is only filled during the rainy season. They have to travel a lot of distance to have pure water.

- Irrigation Problem: People of Badliya face problem at time of irrigation. They use wells and tube wells for the irrigation of land. Due to uneven electricity distribution, power cut off many time whole day. They failed to irrigate their land in proper way. Some area of land get wet and some area don't get proper water. Flow of water at time of irrigation is not in continuation due to cut off power supply.

- No public amenities:

$>$ Small community hall: The community hall provided in the village is so small that organising a function there not possible and even it is not well maintained and not even much used by the villagers.

$>$ Medical store: There is no medical store and do not even facilitate proper medicines in the dispensary. Villagers are not even aware about what correct medicines should be taken.

Published By: 


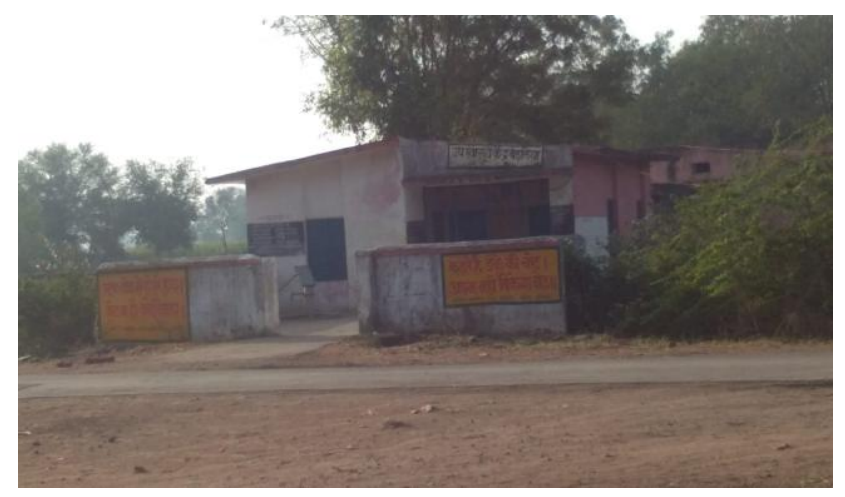

Fig. 5: Existing Primary Health Centre

- Scarcity of potable water: Potable water isn't easily accessible to them. The water reservoir, there isn't having much capacity and it is only filled during the rainy season. They have to travel a lot of distance to have pure water.

- Electrification facility is there but with the low voltage

- No solid waste treatment: The villagers dispose all their waste on the roads only. There is no proper system for waste disposal and not even a single site for waste disposal. There are no dustbins installed in the village.

- Improper sanitation system:

The sewage pipes from their houses are left open to the roads and all the liquid waste from their houses damage the roads and the inner roads are not even so well developed. These kinds of improper sanitation ruin the cleanliness of the village.

\section{PLANNING OR STRATEGIES:}

This topic contains our planning and measures that have been decided to overcome the problems of the villagers

- Electricity: Street light with solar panels is best solution for electricity in common places. The alternative sources will be applicable on the basis of UJALA YOJANA which aims to promote the efficient use of energy at residential use.

- Roads: Marking all the roads in the village map and proposing a plan for the kuccha and rough roads to be replaced by the $\mathrm{CC}$ roads. The roads leading to the main village is in the worst condition and this needs to be constructed in accordance to the profile of the village. We will also add the removal of the public encroachments with the plan and a proper drainage system at both the sides of the road.

\section{- $\quad$ RETAINING Wall}

\section{$>$ Purpose of Retaining Wall}

Badliya is situated near the bank of river which is connected to Kagdi Dam. When water released from dam during rainy season, level of river increases and flows with great velocity. Due to this, water exerts great force at the delta that starts erosion. Farms situated at the delta region face great loss of land due to erosion. Nearly 10 bigha land has eroded in last 10 years.

\section{$>$ Proposal}

By making retaining wall at the area where erosion takes place in greater quantity,

We save cultivated land which helps the people of that area. This retaining wall neglects the thrust exerted by water and reduce the effect of erosion.
- Solid Waste Management and Proper Drainage System: Door to door garbage collection system and drainage system at each household are required.

- Planning for the primary health center with medical store facility is required and Fig. 6 shows 3d planning model of required Medical centre for smart village.

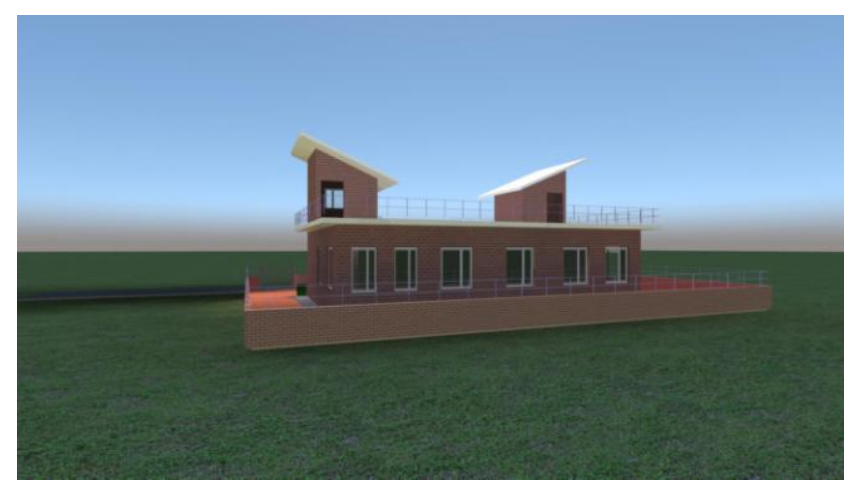

Fig. 6: 3D view of Medical Centre for village

- Community Hall: We have proposed a plan for community hall (Fig. 7) replacing the old one and this hall would be constructed at a new place in the village. This hall will have a space even for the training and parking.

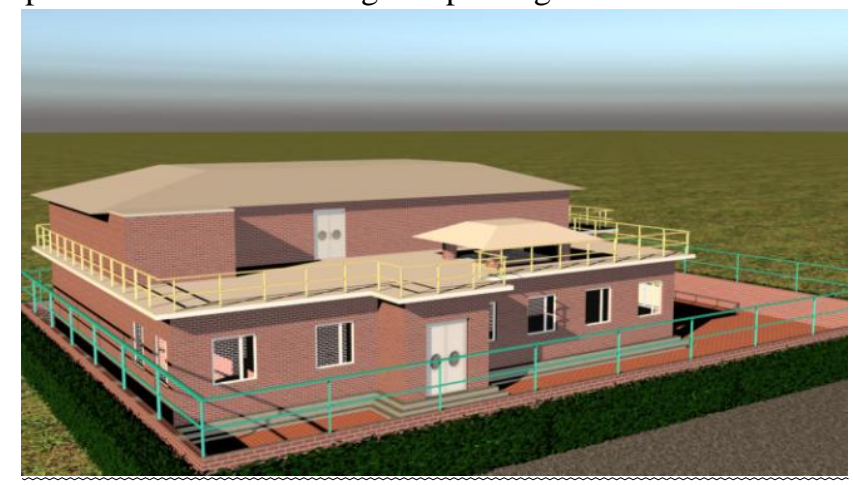

Fig. 7:Proposed Community Hall

- Drinking water: Government has provided small tank filling water station at particular distance but their installation has also been of much time and not even maintained properly so they are a old kind of source. For the accessibility of more water we will give the contour map of the village because it is situated in a valley region so water can be easily collected during the rain. We will also provide the contour map of the water reservoir separately so as to know about its capacity.

- School and Higher education: Smart school could be developed only by the installation of Holistic Quality Education Improvement System (HQEIS). A training program or a kind of workshop would be organised for the teachers in every particular time period for their skill development and for to improve their teaching style. 


\section{CONCLUSION}

People in the villages are not provided all the facilities as compare in the city but by this project they will also live a life of city.

The migration of people from the villages due to less facilities and better employment conditions, will completely stop. They don't have to go out anywhere as they will get all the facilities in their village only. They will be informed about everything happening in the outside world and would then become completely socialize.

\section{REFERENCES}

1. International Journal of Scientific \& Engineering Research, Volume 7, Issue 6, June-2016 395 ISSN 2229-5518 IJSER (C) 2016 http://www.ijser.org; "Study and development of village as a smart village" by Rutuja Somwanshi, Utkarsha Shindepatil, Deepali Tule, Archana Mankar, Namdev Ingle.

2. Sustainability 2018, 10, 2559; doi:10.3390/su10072559 . "Smart Villages: Comprehensive Review of Initiatives and Practices" by Veronika Zavratnik, Andrej Kos and Emilija Stojmenova Duh

3. "Design of Smart Villages" by N. Viswanadham, Computer Science and Automation, Indian Institute of Science, Bangalore Centre for Contemporary Studies, February 6, 2014

4. "Smart Villages" A Pocket guide to rural energy \& "Smart Village"

5. www.conferenceworld.in ISBN: 978-93-87793-0303 "Detailed Project Report On Smart Village Kandalgaon"

\section{AUTHORS PROFILE}

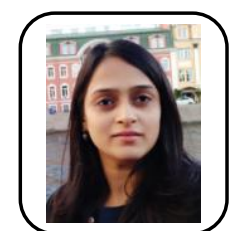

Dr. Sangeeta Choudhary, B.E in Civil Engineering. MBM Engineering College M.E. and $\mathrm{PhD}$ in Environmental Engineering from MBM Engineering College, Jodhpur Associate Professor, Techno India NJR Institute of Technology, Udaipur

- Best Paper Presentation Award at International Conference in Indore

- Rain water Harvesting Project has been selected as Finalist by NITI Aayog for Atal Innovation Mission in 2019.

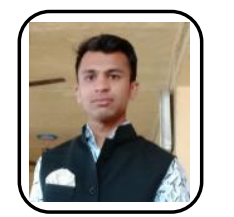

Om Prakash Prajapat, B.Tech.III Year Student of Civil Engineering from Techno India NJR Institute of Technology, Udaipur.

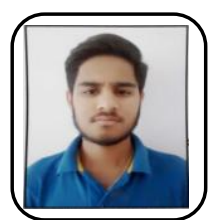

Bhuvnesh Suthar B.Tech. III Year Student, Civil Engineering from Techno India NJR Institute of Technology, Udaipur.

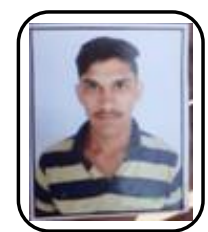

Suresh Kumar, B.Tech. III Year Student, Civil Engineering from Techno India NJR Institute of Technology, Udaipur.

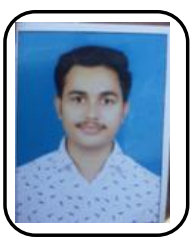

Mahendra Kumar, B.Tech. III Year Student, Civil Engineering from Techno India NJR Institute of Technology, Udaipur. 